\title{
PERKEMBANGAN KONSTELASI POLITIK INTERNASIONAL DAN IMPLIKASINYA TERHADAP POLITIK HUKUM NASIONAL INDONESIA DALAM PEMBERANTASAN TERORISME
}

\author{
Mardenis \\ Fakultas Hukum Universitas Andalas Padang
}

\begin{abstract}
The problem of terrorism has now become one of the few global issues which are very much talked about and greatly affect international relations. Actually, when the United States (U.S.) makes the issue of terrorism as the main agenda of foreign policy (polugri) country and invite / pressing other countries to support it, almost all world countries basically agree, agree. The problem then arises when the execution was terrorism that will be the common enemy of mankind and must be fought together it is terrorism by political interests, and ideology economi U.S.
\end{abstract}

Key words: Terrorism, global issue, US foreign policy, political, economy and ideology of US.

\begin{abstract}
Abstrak
Masalah terorisme saat ini telah menjadi salah satu isu global yang sangat hangat dibicarakan dan sangat mempengaruhi hubungan internasional. Sebenarnya ketika Amerika Serikat (AS) menjadikan isu pemberantasan terorisme sebagai agenda utama kebijakan politik luar negerinya dan mengajak/ menekan negara-negara lain agar mendukungnya, negara- negara lain tersebut setuju- setuju saja. Permasalahan baru muncul ketika dalam pelaksanaannya ternyata terorisme yang dijadikan gerakan bersama negara- negara dunia untuk diperangi tersebut adalah terorisme menurut konsep dan kepentingan politik, ekonomi dan ideologi AS.
\end{abstract}

Kata Kunci: Terrorisme, isu global, polugri AS, kepentingan politik, ekonomi dan ideologi AS.

\section{Pendahuluan}

Beberapa studi membuktikan bahwa hukum merupakan produk politik sehingga karakter isi setiap produk hukum akan sangat di tentukan atau diwarnai oleh imbangan kekuatan atau konfigurasi politik yang melahirkannya. Studi lain sebaliknya berpendapat bahwa hukum suatu bangsa sesungguhnya merupakan pencerminan kehidupan sosial budaya bangsa dan masyarakat yang bersangkutan.

Pendapat yang disebut terakhir ini mengandung makna bahwa hukum yang dibentuk seharusnya sesuai dengan aspirasi dan kesadaran hukum masyarakatnya. ${ }^{1}$ Untuk konteks Indonesia, maka produk hukum yang dibentuk harus sesuai dengan nilai-nilai Pancasila sebagai

\footnotetext{
Lihat Umbu Lily Pekuali, "Memposisikan Hukum sebagai Penyeimbang Kepentingan Masyarakat", Jurnal Pro Justitia, Vol. 26 No. 4 Oktober 2008, FH Unpar Bandung, hlm 359-370.
}

sumber dari segala sumber hukum yang berlaku di Indonesia.

Terlepas dari berbagai pendapat yang ada, suatu kenyataan yang tidak dapat dipungkiri, bahwa pembentukan hukum di suatu negara termasuk di Indonesia tidak dapat dilepaskan dari pengaruh sistem politik yang berlaku, baik pengaruh sistem politik domestik, begitu juga pengaruh dinamika dan perkembangan konstelasi politik internasional. ${ }^{2}$

Berkaitan dengan perkembangan konstelasi politik internasional kontemporer, dengan berakhirnya perang dingin sejak awal tahun 1990-an, telah mengantarkan dunia ke alam hubungan internasional baru, dengan beberapa ciri perkembangan yang berbeda secara funda-

\footnotetext{
Lihat dan bandingkan dengan Atom Ginting Munthe, "Postur "Rasionalis" dalam Politik Luar Negeri Indonesia Pasca Suharto" J urnal Hukum Pro J usitia, Vol. 24 No. 3 J uli 2006, hlm. 191-202.
} 
mental dibandingkan dengan ketika masih berlangsungnya perang dingin.

Beberapa perubahan besar yang terjadi dapat disebutkan. Pertama, terjadinya perubahan dalam tata hubungan internasional dari bipolar menjadi multipolar yang ditandai dengan tampilnya Amerika Serikat (AS) sebagai Negara Adi daya satu-satunya bersama dengan Negara-negara Barat lainnya yang bersumbu pada kekuatan-kekuatan politik ekonomi di Amerika Utara, Eropa dan Asia Timur; kedua, meningkat derasnya era globalisasi dan interdependensi antara berbagai masalah global dalam berbagai bidang seperti politik, ekonomi, social, keamanan, lingkungan hidup dan yang terakhir terorisme; ketiga, mencuatnya masalah-masalah transnasional yang ditonjolkan oleh pihak Barat terutama AS, seperti masalah HAM, Demokrasi, Good governance, lingkungan hidup dan terorisme; dan keempat, menguatnya peran actor non pemerintah termasuk NGO dalam percaturan internasional atau multi track diplomasi dalam hubungan internacional. ${ }^{3}$

Setelah perang dingin berakhir, Barat memiliki pandangan dan kebijakan khusus terhadap dunia Islam. Dimasa perang dingin, Komunisme dianggap sebagai musuh utama, sehingga seringkali Barat bergandengan tangan dengan Islam menghadapi komunisme, serperti yang terjadi di Afganistan. Tetapi, setelah Komunisme runtuh, Barat harus menetapkan musuh baru, sebagai pengganti Komunisme. Berkaitan dengan hal ini, para aktifis Neo-Konservatif (Kelompok Kristen Fundamentalis, Yahudi sayap kanan, politisi republik, dan ilmuwan Neo-Orientalis), berhasil menjalankan agenda internasional pasca perang dingin ${ }^{4}$.

Islam dipandang sebagai ancaman potensial bagi Barat, atau Islam dipandang sebagai isu politik potensial untuk meraih kekuasaan di Barat, maka berbagai daya upaya dilakukan untuk 'menjinakkan' dan melemahkan Islam.

Interim Report, Revitalisasi Proses Pembuatan Kebijakan Luar Negeri Indonesia Menghadapi Perkembangan Internal dan Eksternal, Laporan Penelitian, Deparlu RI, 2002, hlm. 28

4 Tentang strategi Barat dalam menghadapi Islam pasca perang dingin, lihat, Adrian Husaini, 2005, Wajah Peradaban Barat: Dari Hegemoni Kristen ke Dominasi Sekular-Liberal, J akarta: GIP.
Peledakan bom Bali pada 12 Oktober 2002 yang menewaskan lebih kurang 185 jiwa dan menjadi alasan utama pemerintah untuk mengeluarkan undang-undang pemberantasan terorisme di Indonesia, ditenggarai banyak kalangan sebagai bahagian dari upaya konspirasi kekuatan politik internasional dengan keuatan politik elit nasional tertentu untuk memojokkan kekuatan Islam di Indonesia yang saat itu gencar menyuarakan pemberlakukan syariat Islam melalui jalur politik (parlemen).

Sehubungan dengan ini, Adian Husaini ${ }^{5}$ menyatakan bahwa salah satu program yang kini dilakukan Barat adalah dengan melakukan proyek liberalisasi Islam besar-besaran di Indonesia dan dunia Islam lainnya, termasuk liberalisasi dibidang regulasi nasionalnya.

Sehubungan dengan semakin begitu kuatnya pengaruh relasi politik internasional khususnya AS dan sekutu-sekutunya terhadap kebijakan domestik khususnya Negara-negara Berkembang termasuk Indonesia, maka semakin terasalah kebenaran pendapat Juwono Sudarsono yang menegaskan bahwa "rumusan lama mengenai politik luar negeri adalah kepanjangan dari kepentingan politik dalam negeri, sudah usang serta harus diganti dengan politik dalam negeri adalah reaksi terhadap tantangan besar yang disebabkan perkembangan internasional." 6

Perjalanan sejarah pembentukan hukum di Indonesia, tidak dapat dilepaskan dari pengaruh dinamika konstelasi politik internasional, yang mempengaruhi corak sistem hukum Indonesia. Pengaruh konstelasi politik internasional yang dimaksud terutama adalah pengaruh kepentingan politik dan idiologi Negara Adikuasa (AS) baik dalam proses pembentukan undang-undang (di DPR), begitu juga dalam penerapan dan penegakan hukum (hukum pidana formil dan materil) nya. Produk hukum yang dimaksud terutama produk hukum yang "kental" dengan muatan ideologis dan aspek inter-

Adian Husaini, Liberalisasi Islam di Indonesia, Makalah disampaikan dalam forum kerjasama Pondok Pesantren Indonesia (BKSPPI), Bogor, 2 April 2006 hlm. 52.

6 J uwono Sudarsono, dalam K.J. Holsty, 1987, Politik Internasional (Kerangka Analisa), Jakarta: Pedoman IImu J aya, hlm. v 
nasionalnya. Dalam tulisan ini penulis sengaja memilih satu contoh produk hukum sebagai objek pembahasan yakni: Undang-undang Nomor 15 dan 16 Tahun 2003 dan Perppu Nomor 2 Tahun 2002 mengenai Pemberantasan Terorisme.

Argumen yang dipakai dalam penentuan produk hukum di atas adalah dengan anggapan sebagai berikut. Pertama, jenis produk hukum tersebut jika dilihat dari sudut pohon ilmiah hukum, termasuk dalam lingkup hukum pidana dan tata negara yang kental dengan aspek politisnya, terutama politik internasional. Kedua, produk hukum tersebut substansinya berkaitan erat dengan isu penting, yang saat ini merupakan bagian dari isu global (the global issue) yang sangat mempengaruhi hubungan internasional kontemporer. Ketiga, dalam proses pembentukan dan penegakkan produk hukum ini diwarnai oleh hal-hal yang bersifat kontroversial, seperti diberlakukannya azas "retroaktif" terhadap tertuduh pelaku bom Bali yang kemudian dibatalkan oleh Mahkamah Konstitusi (Putusan MK No. 013/ PUU-I/ 2003 tanggal $22 \mathrm{~J} \mathrm{u-}$ li 2004). Penangkapan, penahanan, dan vonis terhadap terpidana Abu Bakar Baasyir yang juga terkesan kuat ada intervensi/tekanan asing, begitu juga proses penangkapan terhadap tersangka teroris Abu Dudjana yang juga kental dengan dugaan pelanggaran HAM oleh aparat kepolisian.

Berkenaan dengan itu maka tulisan ini menggunakan pra anggapan bahwa perkembangan konstelasi politik Internasional memberikan implikasi yang cukup besar (signifikan) terhadap pembentukan dan penegakkan undang-undang pemberantasan terorisme di Indonesia.

Berdasarkan uraian pada bagian pendahuluan di atas, penulis mencoba merumuskan serta mengidentifikasi masalahnya sebagai berikut. Pertama, apakah politik hukum nasional Indonesia dalam pemberantasan terorisme telah sesuai dengan prinsip-prinsip negara hukum berdasarkan Pancasila dan UUD-1945?; kedua, bagaimanakah perkembangan konstelasi politik internasional dalam pemberantasan terorisme dewasa ini dikaitkan dengan asas-asas negara hukum yang demokratis?; dan ketiga, sejauh manakah perkembangan konstelasi politik internasional berimplikasi terhadap politik hukum nasional Indonesia dalam pemberantasan terorisme?

\section{Pembahasan \\ Politik Hukum Pemberantasan Terorisme di Indonesia}

Serangan atas gedung WTC dan gedung Pentagon AS oleh para teroris tanggal 11 September 2001, telah mendorong pemerintah AS dan negara-negara Barat lainnya untuk memperbaharui Undang-undang (UU) Anti Terorisme mereka dengan tujuan untuk memperluas dan memperkuat kewenangan aparat negara masing-masing dalam melakukan penyelidikan, penyidikan, dan serangkaian tindakan koersif lainnya yang dipandang perlu untuk kesuksesan kampanye perang melawan terorisme (war on terrorism). ${ }^{7}$

Sementara itu, terhadap dunia internasional salah satu isu penting yang sering di kemukakan AS dan negara sekutunya dalam kampanye anti teroris (war on terorrism) nya adalah nilai kemanusiaan. AS menganggap bahwa serangan 11 September 2001 yang telah meIuluh-lantakkan gedung kebanggaan warga AS, WTC dan gedung pertahanan AS Pentagon, merupakan serangan terhadap kemanusiaan yang mengancam peradaban dunia. Dengan demikian, tragedi 11 September 2001 merupakan tragedi kemanusiaan tidak hanya bagi AS tapi juga bagi seluruh peradaban umat manusia. Dalam pidatonya pada tanggal 11 Oktober 2001, Presiden Bush menyatakan, “.... serangan ini terjadi di Amerika, tapi menyerang jantung dan jiwa peradaban dunia. ${ }^{8}$

\footnotetext{
7 Lihat dan bandingkan dengan tulisan Sukawarsini Djelantik, "Terorisme dan Keamanan Nasional", J urnal IImu Hubungan Internasional Vol. 1 No. 1 Centre for International Studies, Unpar, Bandung.

8 Jaringan Teroris, Deparlu AS, dalam Farid Wadjdi, "Kebencian Barat Terhadap Gerakan Islam Idiologis", Wahyu Press, Jakarta, 2003, hlm. 28. Baca juga Merlina Lim, "Islamic Radicalism and Anti-Americanism in Indonesia, The Role of the Internet", Policy Study No. 18, 2005. Baca juga Ethan Bueno de Mesqueta, "The Quality of Terror", American Journal of Political Science, 2005, Midwest Political Science Association.
} 
Berdasarkan cara berpikir demikian, AS kemudian secara sistematis membangun opini internasional bahwa kampanye anti terorisme yang dipeloporinya merupakan upaya membela kemanusiaan. Berdasarkan ini pulalah AS melegitimasi aksinya keseluruh dunia, seperti menyerang ke Afghanistan dan invasi ke Irak, mengelompokkan group atau orang tertentu sebagai teroris, menangkap, membekukan aset dan tindakan lain yang dianggap penting oleh AS, termasuk menekan negara-negara lain (khususnya Negara-negara berkembang, temasuk Indonesia) agar menyesuaikan regulasi nasionalnya dengan kepentingan AS dalam memerangi terorisme dan melindungi nilai-nilai kemanusiaan tersebut. Jika negara yang "bandel", tidak mendukung kepentingan AS tersebut, termasuk tidak mau menyamakan regulasi nasionalnya dengan kemauan AS, maka dikategorikan sebagai negara yang mendukung terorisme yang otomatis menjadi musuh AS ("He who is not with us is against us"), seperti Iran, Irak, Suriah, Libanon, dan lain-lain. ${ }^{9}$

Sebagai "respon" terhadap tekanan AS tersebut, banyak negara-negara kemudian memperbaharui UU Anti Terorismenya sesuai dengan kemauan dan kepentingan AS. Di Kanada, pemerintah yang di kendalikan oleh partai Liberal mengajukan RUU yang dimaksudkan untuk mereformasi UU Anti Terorismenya. RUU (Bill C-36) menetapkan suatu aturan baru tentang tindak pidana terorisme yang untuk memberantasnya negara akan mempunyai kekuasaan yang khusus untuk melakukan investigasi dari penuntutan. Termasuk dalam kekuasaan yang khusus itu adalah penahanan preventif (preventive detention), hak untuk mengurung (incarcevate) orang-orang atas dasar semata karena adanya kecurigaan, bahwa mereka akan melakukan kejahatan, kekuasaan baru diberikan kepada polisi untuk memaksa kesaksian dari orang yang mereka percaya mempunyai informasi yang berkaitan dengan investigasi terorisme, peradilan tertutup (close trial) dan penuntutan atas persetujuan hakim, penging-

9 Lihat, Bagas Hapsoro, dalam Hubungan Internasional : Percikan Pemikiran Diplomat Indonesia, Deparlu RI, 2004, hlm. 197 karan terhadap tersangka dan penaseat hukumnya atas seluruh pengetahuan pembuktian terhadapnya. RUU tesebut sangat meningkatkan kewenangan polisi untuk melakukan pengawasan, sementara secara dramatis meningkatkan prerogatif pemerintah untuk menahan (suppress) informasi mengenai kegiatankegiatannya. ${ }^{10}$

Sementara di Prancis, juga telah dilakukan reformasi terhadap UU Anti Terorismenya. UU Prancis yang baru memperluas kekuasaan polisi untuk menggeledah benda-benda pribadi (private property), termasuk mobil dan mendukung keselamatan di tempat-tempat publik, seperti pusat-pusat perbelanjaan, fasilitas olah raga, bandara, dan pelabuhan-pelabuhan. ${ }^{11}$

Upaya untuk memperbaharui UU Anti Terorisme yang mengarahkan pada penguatan dan pelaksanaan kekuasaan atau wewenang aparat penegak hukum, juga dilakukan di negara-negara sekutu AS lainnya seperti Australia, Inggris, dan lain-lain. Pada hal sesuai dengan prinsip-prinsip negara hukum dan demokrasi yang dipahami secara universal oleh masyarakat internasional, upaya untuk memperbaharui UU Anti Terorisme dengan cara memperluas kewenangan aparat penegak hukum can intelijen dan mengintervensi hak-hak pribadi (privacy) merupakan tindakan yang bertendensi sebagai sebuah kemunduran (set back) bagi kebebasan sipil yang merupakan bagian penting dari hakhak asasi manusia (HAM) seyogianya dilindungi oleh negara/bangsa beradab (Civilized $\mathrm{Na}$ tion). ${ }^{8}$

Setelah tragedi 11 September 2001 yang menimpa gedung WTC dan gedung Pertahanan Pentagon, AS tanggal 12 Oktober 2002, teroris kembali beraksi di Indonesia tepatnya di Legian, Kuta, Bali yang menewaskan lebih dari 180 orang, dan yang luka-luka mencapai lebih 300 orang.

Moch. Faisal Salam, idem, hlm. 180-181

1 Ibid

8 Lihat dan bandingkan dengan tulisan Anak Agung Banyu Perwita, "Penegakan HAM dan Politik Luar Negeri Indonesia", J urnal Hukum Pro Jusitita, Vol. 24 No. 2 April 2006, hlm. 112-120; Mike Fell, "Is Human Security Our Main Concern in the $21^{\text {st }}$ ?", Journal of Security Sector Management, Vol. 4 No. 3, September 2006. 
Hanya 3 hari setelah tragedi 12 Oktober di Legian, Bali, Dewan Keamanan PBB pada tanggal 15 Oktober 2002 mengeluarkan sebuah resokesi baru No. 1438 yang isinya selain mengecam terorisme, juga berisi permintaan agar seluruh 15 negara anggota Dewan Keamanan PBB membantu Indonesia untuk menyeret para pelaku, pengorganisasi dan sponsor serangan teror di Bali ke pengadilan. ${ }^{12}$

Seluruh 15 anggota DK PBB secara bulat menyatakan setuju dalam voting untuk resolusi 1438, yang menggambarkan bahwa serangan teroris di Bali sebagai sebuah ancaman bagi perdamaian dan keamanan internasional. Resolusi tersebut juga mengingatkan kewajiban seluruh anggota PBB untuk bekerja sama memerangi terorisme. Sebelum mengeluarkan resolusi 1438 tersebut, PBB telah terlebih dahulu berkonsultasi dengan Indonesia. Dalam pernyataannya, DK PBB tidak hanya prihatin dengan jumlah korban yang kehilangan jiwa tetapi juga akan dampak tragedi Bali pada ekonomi Indonesia. ${ }^{13}$

Akhirnya, menanggapi Resolusi DK PBB Nomor 1438, pemerintah Indonesia pada tanggal 18 Oktober 2002 telah mengeluarkan dua Peraturan Pemerintah Pengganti Undang-undang (PERPPU) Republik Indonesia. Pertama, Perppu Nomor 1 Tahun 2002, tentang Pemberantasan Tindak Pidana Terorisme yang tidak berlaku surut; dan kedua, Perppu Nomor 2 Tahun 2002, tentang Pemberlakuan. Perpu Nomor 1 Tahun 2002, tentang Pemberantasan Tindak Pidana Terorisme Pada peristiwa Peledakan Bom di Bali, tanggal 12 Oktober 2002 yang berlaku surut.

Kedua Perppu di atas, mulai berlaku pada 18 Oktober 2002, dan selanjutnya tanggal 4 April 2003 disahkan sebagai Undang-undang RI Nomor 15 dan 16 Tahun 2003 tentang Pemberantasan Tindak Pidana Terorisme.

Salah satu pertimbangan yang dimuat dalam konsideran kedua peraturan tersebut adalah bahwa pemberantasan terorisme di

12 Hadi Setia Tunggal, 2003, Peraturan Perundang-undangan tentang Terorisme, J akarta: Harvarindo, hlm. 111

13 Ibid. Lihat dan bandingkan dengan tulisan Ozler Alesina, dan Swagel, "Political Instability and Economic Growth", J ournal of Economic Growth, Vol. 1, 1996. dasarkan pada komitmen nasional dan internasional dengan membentuk peraturan perundang-undangan nasional yang mengacu pada konvensi internasional dan peraturan perundang-undangan nasional yang berkaitan dengan terorisme.

Berdasarkan uraian serta salah satu konsideran sebagaimana disebutkan di atas serta fakta bahwa sekitar dua minggu pasca tragedi 11 September 2001, presiden Indonesia, Megawati, melakukan kunjungan resmi ke $A S$, di peroleh gambaran bahwa kelahiran Undangundang Pemberantasan Terorisme di Indonesia disamping sebagai reaksi terhadap situasi dalam negeri khususnya terkait dengan tragedi Bom di Bali, tetapi juga sulit dilepaskan dari bayang-bayang tekanan dan kepentingan internasional, terutama AS.

Asumsi ini semakin diperkuat oleh fakta bahwa secara substantif kedua undang-undang tersebut mengandung banyak pasal kontroversial yang isinya sejalan dengan Undangundang Anti Terorisme AS (UU Patriot) yang intinya memberikan kekuasaan luas kepada aparat penegak hukum dan intelijen dalam mengintervensi hak-hak pribadi (privacy) masyarakat. Kesan ini semakin dipekuat oleh fakta lain dimana detasemen khusus (densus) 88 Anti Terorisme Polri pelatihannya dilaksanakan di AS atas biaya AS dan oleh instruktur-instruktur AS.

Pengamat politik dari Lembaga IImu Pengetahuan Indonesia (LIPI), Indra Samego, menyatakan bahwa pemberlakuan UU Nomor 15 Tahun 2003 tentang Pemberantasan Tindak Pidana Terorisme, sangat tendensius dan diskriminatif terhadap umat Islam. Ini sama halnya Indonesia menari dengan gendang orang lain. ${ }^{14}$ Kedua Perppu tersebut dari awal kehadirannya memang merupakan peraturan perundangan yang cukup kontroversial dan mengundang prokontra dari berbagai kalangan masyarakat.

Perppu ini jelas melanggar azas retroaktif (azas tidak boleh berlaku surat) yang merupakan salah satu azas penting dalam ilmu hukum dan diterima sebagai kebenaran universal oleh masyarakat internsional serta secara

14 Harian Republika, Kamis, 2 Maret 2006 
eksplisit dilindungi, keberadaannya dalam UUD1945 (pasal 28). Hal ini berarti bahwa sejak awalnya Perppu tersebut dapat dikatakan memang telah lahir cacat. Karena itu pula, ketika Perppu Pemberantasan Terorisme masih wacana, banyak kalangan anggota DPR yang menolak kehadirannya. Mutamminul 'Ula, anggota DPR-RI dari Fraksi Keadilan, menyatakan bahwa rencana pemerintah mengeluarkan Perppu Anti Terorisme sebagai reaksi terhadap situasi di dalam negeri khususnya terkait dengan tragedi bom di Bali, merupakan cerminan bahwa pemerintah kurang jernih di dalam melihat sebuah persoalan. Pemerintah seharusnya melihat ke dalam bahwa berbagai aksi teroris di dalam negeri yang selama ini membuat situasi menjadi kacau dan mengganggu keamanan nasional sesungguhnya lebih sebagai akibat dari lemahnya sistem pertahanan dan keamanan negara, khususnya badan intelijen. ${ }^{15}$

Nutamminul, di samping menolak kehadiran Perppu Anti Terorisme ini juga mempertanyakan aspek legalitas dari Perppu. Sebagaimana diketahui, pembentukan Perppu mengacu pada ketentuan Pasal 22 ayat (1) UUD 1945 yang menyebutkan, "Dalam hal ihwal kegentingan yang memaksa, Presiden berhak menetapkan peraturan pemerintah sebagai pengganti undang-undang". Dalam hal ini, Nutamminul menegaskan

“.... ditinjau dari segi apapun situasi dan kondisi di dalam negeri saat ni belum dapat dikaterorikan sebagai keadaan yang genting dan memaksa sebagaimana dimaksud UUD-1945. Kondisi memaksa adalah kondisi di mana penyelenggaraan pemerintahan mengalami krisis yang amat membahayakan. Kejadian bom di Bali berikut dampak yang ditimbulkan tidak bisa ditafsirkan sebagai kondisi yang memaksa itu. Kenyataannya proses penyelenggaraan pemerintahan masih berjalan seperti biasa dan kehidupan warga masyarakat Indonesia, khususnya Bali berjalan normal-normal saja". ${ }^{16}$

\footnotetext{
15 Nutammimul 'Úla, dalam 'Risalah Perjuangan Dakwah Perlemen', PT. Era Adicitra Intermedia, Solo, 2004, hlm. 28

16 Ibid.
}

Tingkat penolakan dan resistensi masyarakat terhadap kehadiran Perppu Pemberantasan Terorisme semakin meluas ketika Perppu No. 1 Tahun 2002 dan No. 2 Tahun 2002 mengenai pemberantasan terorisme tersebut di bahas di DPR-RI untuk disahkan. Dalam rapat paripurna pengesahan Perppu No. 1 Tahun 2002 tentang Pemberantasan Tindak Pidana Terorisme menjadi undang-undang, tanggal 6 Maret 2003, sejumlah anggota DPR dari Fraksi Reformasi dan Fraksi Danlatul Ummah melakukan aksi walk out dari sidang.

Hartono Mardjono - juru bicara Fraksi Perserikatan Danlatul Ummah - mengemukakan bahwa, "perppu tidak memiliki landasan yang sah bahkan dapat dikatakan inkonstitusional. Karena itu, batal demi hukum". ${ }^{17}$ Dalam sidang paripurna pengesahan Perppu menjadi UU Pemberantasan Terorisme tersebut, Hartono Marjono juga mempertanyakan landasan konstitusional dari pembuatan perppu tersebut yang menurutnya tidak sesuai dengan pasal 22 UUD1945. Menurutnya, dalam enam butiran konsideran perpu bersebut, tidak ada satu klausul pun yang menyatakan bahwa negara dalam keadaan ganting yang memaksa, sebagaimana depersyaratkan oleh Pasal 22 ayat (1) UUD 1945 "Kata-kata genting yang memaksa harus dicantumkan", tegasnya. ${ }^{18}$

Fraksi lainnya yang juga menolak pengesahan Perppu Nomor 1 dan 2 Tahun 2002 tentan Pemberantasan Tindak Pidana Terorisme menjadi undang-undang adalah Fraksi Reformasi. Dalam pendapat akhir fraksi ini, ditegaskan bahwa unsur prasyarat pembentukan perppu yaitu "hal ikhwal kegentingan yang memaksa" tidak terpenuhi dalam pembentukan perppu di atas, yang nyata-nyata tidak dicantumkan dalam konsideran perppu. ${ }^{19}$ Selanjutnya Fraksi Reformasi juga memberikan catatan bahwa proses dan mekanisme pengundangan perppu saat itu juga tidak sesuai dengan ketentuan Tata Tertib DPR-RI, yang Pasal 31 (1) nya berbunyi "Terhadap pembahasan dan penyelesaian

Ibid, hlm. 30

18 Ibid, hlm. 30-31

19 Pendapat Akhir Fraksi Reformasi DPR-RI disampaikan pada siding tanggal 6 Maret 2003, Sumber, Biro Persidangan DPR-RI, 2003, hlm. 3 
perppu berlaku ketentuan sebagaimana dimaksud dalam Pasal 120, 121 dan 122 dengan memperhatikan ketentuan yang khusus berlaku bagi rancangan undang-undang yang berasal dari pemerintah. Sehubungan dengan hal ini, Fraksi Reformasi mencatat dan berpendapat, sejak perppu disampaikan oleh presiden ke DPR, lembaga ini belum pernah memenuhi prosedur pembahasan sebagaimana dimaksud dalam tata tertib tersebut. ${ }^{20}$

Fraksi Kebangkitan Bangsa, kendatipun untuk menghindari kekosongan hukum akhirnya menyatakan setuju terhadap pengesahan perppu No. 1 dan 2 Tahun 2002 tentang Pemberantasan Tindak Pidana Terorisme menjadi undang-undang, tetapi fraksi ini memberikan persetujuannya dengan disertai catatan-catatan kritis, antara lain agar Pemerintah menggunakan UU tentang Penetapan Perppu menjadi Undang-undang ini secara bertanggung jawab, tidak melampaui batas kewenangannya, dan tidak membuat penafsiran implementasinya hanya menurut kehendak dan kepentingan politik pemerintah serta tidak menjadikannya sebagai alat kekuasaan untuk menghadapi pihak-pihak yang bersikap kritis kepada pemerintah. ${ }^{21}$.

Kontroversi atas perppu No. 1 dan 2 Tahun 2002 yang kemudian disahkan menjadi UU No. 15 dan 16 Tahun 2003 tentang Pemberantasan Terorisme semakin lengkap menjadi sorotan publik setelah keluarnya Putusan MK No. 13/ PUU-I/ 2003 tanggal 22 J uli 2004 yang membatalkan Pemberlakuan Surut UU No. 15 Tahun 2003 untuk kasus Bom Bali yang oleh banyak kalangan dinilai sebagai keputusan yang sangat progresif dan positif dalam upaya mewujudkan negara hukum yang berkeadilan, sekaligus juga merupakan langkah berani untuk menunjukkan kemandirian MK sebagai "the guardian of constitution" di Indonesia.

\section{Perkembangan Konstelasi Politik Inter- nasional dalam kaitannya dengan Pemberan- tasan Terorisme dewasa ini.}

\footnotetext{
20 Pendapat Akhir Fraksi Reformasi, idem, hlm. 4

21 Pendapat Akhir Fraksi Kebangkitan Bangsa DPR-RI, sumber : Biro Persidangan DPR-RI, 2003, hlm. 7
}

K.J. Holsty menyatakan bahwa kebanyakan studi politik internasional (World Politics) merupakan studi mengenai kebijakan politik luar negeri, dimana kebijakan ini didefinisikan sebagai keputusan-keputusan yang merumuskan tujuan menentukan preseden, atau melakukan tindakan-tindakan tertentu, dan tindakan yang diambil untuk mengimplementasikan keputusan-keputusan itu. Studi-studi ini memusatkan perhatian pada usaha-usaha menggambarkan tindakan dan elemen-elemen kekuasaan negara-negara besar. ${ }^{22}$

Berdasarkan pengertian-pengertian di atas diperoleh gambaran bahwa politik internasional pada dasarnya merupakan kebijakan politik luar negeri negara-negara besar dalam memperjuangkan kepentingan nasional negara masing-masing yang dalam perwujudannya dapat berbentuk konflik, kompetisi, kerjasama dan akomodasi. Dengan demikian dapat juga di tegaskan bahwa jika saat ini negara besar yang memiliki kekuatan hegemoni terhadap negaranegara lain adalah negara Amerika Serikat (AS) dengan negara-negara sekutu Baratnya seperti Inggris, J erman, Prancis dan lain-lain, maka politik internasional kontemporer pada dasarnya merupakan kebijakan politik luar negeri AS dan negara-negara sekutunya dalam tatanan hubungan internasional.

Setelah perang dingin berakhir, Barat memiliki pandangan dan kebijakan khusus terhadap dunia Islam. Dimasa perang dingin, Komunisme dianggap sebagai musuh utama, sehingga seringkali Barat bergandengan tangan dengan Islam menghadapi komunisme, serperti yang terjadi di Afganistan. Tetapi, setelah Komunisme runtuh, Barat harus menetapkan msuh baru. Musuh baru itu adalah Islam dan Convisionis $^{23}$. Kendatipun secara formal yang di sebut-sebut Barat sebagai musuh setelah tumbangnya Komunisme adalah Islam dan Convi-

22 K.J. Holsty, Internasional Politics, A Frame Work for Amalysis ( Terj. Oleh Efin Sudrajat, dkk ), Pedoman Ilmu J aya, J akarta, 1987, hlm. 28

23 Teori ini diintrodusir oleh Samuel P. Huntington dalam artikelnya yang dimuat dalam "Foreign Affair" vol . 72 no. 3, Summer 1993, hlm. 22-49. Dalam artikel tersebut, Huntington mengemukakan teorinya tentang "the clash of civilization", yakni benturan peradaban antara Barat vs Islam dan Convisionis. 
sionis, tetapi dalam realitanya yang sering menjadi sasaran serangan anarkisme Barat adalah Dunia Islam, antara lain dengan memanfaatkan isu perang melawan terorisme (war on terrorism).

Oleh karena Islam dipandang sebagai ancaman potensial untuk meraih kekuasaan di Barat, maka berbagai daya upaya dilakukan Barat untuk "menjinakkan" dan melemahkan Islam. Menurut Adian Husaini, ${ }^{24}$ salah satu program yang kini dilakukan Barat adalah dengan melaksanakan proyek liberalisasi Islam besarbesaran di Indonesia dan dunia Islam lainnya, termasuk liberalisasi di bidang regulasi nasionalnya.

Ambisi AS untuk melemahkan Dunia Islam, kemudian mendapatkan momentumnya dengan tragedi 11 September 2001. Sejak peristiwa tragis tersebut, AS telah melakukan perubahan drastis dalam polugrinya dari strategi pembendungan (containment) dan penangkalan (deterrence) menjadi serangan dini (pre emptive attack/strike) dan intervensi defensif (defensive intervension). Penggunaan konsep preemptive strike (serangan dini) merupakan strategi keamanan AS paling kontroversial sepanjang sejarah polugrinya menghadapi ancaman terorisme internasional. Berdasarkan strategi pre-emptive strike ini pulalah AS melegitimasi aksinya ke berbagai belahan dunia, antara lain ke Irak dan Afghanistan, serta mengancam negara-negara lainnya agar menyesuaikan regulasi nasionalnya dengan kepentingan AS dalam memerangi terorisme internasional.

AS sebagai negara yang pertama kali mendeklarasikan "war on terrorism" (perang melawan terorime), sangat jelas secara tidak konsisten AS dalam menggunakan istilah terorisme telah menimbulkan kesan bahwa apa yang di sebut dengan perang melawan terorisme oleh AS sesunguhnya merupakan perang melawan pihak-pihak yang mengancam kepentingan AS,

24 Adian Husaini, Liberalisasi Islam di Indonesia, makalah disampaikan pada Forum Kerja Sama Pondok Pesantren Indonesia (BKS-PPI) di Bogor, 2 April 2006, hlm. 52. Lihat juga Al-Habib Muhammad Rizieq bin Husein Syihab, "Sumpah Usamah", Majalah Islam Sabili, No. 12 Tahun X, 2 J anuari 2003/ 29 Syawal 1423; Sidney J ones, "Sayap Garis Keras itu Bernama Thoifah Muqatilah", Majalah Tempo Eisi 17-23 Oktober 2005, hlm. 60-63. baik politik, ekonomi maupun ideloginya dan hal itu bertentangan dengan kenyataan. Sebab merujuk kepada pengertian terorisme yang di ungkap dalam Undang-undang anti terorisme AS, terorisme berkaitan dengan pengunaan kekuatan (force) dalam mencapai tujuan politik internasional.

Kalau pengertian di atas dipakai secara konsisten sebagai referensi tentang terorisme, maka AS lah yang sebetulnya merupakan "gembong teroris" (the real terrorism). Karena AS lah Negara yang senantiasa menggunakan kekerasan apabila kepentingan politiknya (merasa) terancam.

Aksi kekerasan (militer) AS itu selalu di lakukan atas dasar kepntingan ideologi Kapitalisme, baikdalam bidang ekonomi, HAM, maupun demokrasi. Tahun 1945, AS lah yang menggunakan kekuatan bom atom untuk pertama kalinya di Hirosima dan Nagasaki (Jepang). Di Vietnam, AS jugalah yang menjatuhkan bom Napalm dan Agent Orange yang membunuh ratusan orang dan merusak tanah di sana. Demikian juga tindakan AS di Kuba, menyerbu Granada, Afghanistan, Irak, melibatkan diri dalam perang Arab-Israel dan dalam pembantaian Israel terhadap rakyat Palestina. Semuanya jelas didasarkan atas (kepentingan) ideologi Kapitalisme.

Berdasarkan uraian di atas tergambar jelas bahwa sampai saat ini pengertian dan klasifikasi terorisme sangat bias kepentingan, terutama kepentingan politik dan ideologi negara-negara Barat, terutama AS. Ketidak jelasan pengertian dan klasifiklasi mengenai terorisme ini, membuat banyak pihak skeptis terhadap kebijakan internasional memerangi terorisme. $^{9}$

Secara teoritis, ada dua pandangan yang sangat berbeda secara fundamental dalam me-

\footnotetext{
Biasnya klasifikasi dan pengertian serta upaya mengklaim apa dan siapakah teroris itu diperparah dengan penguasaan media massa oleh kelompok yang mayoritas pro status quo, sehingga pandangan yang jernih sulit untuk didapatkan. Lihat pengaruh media pada terorisme ini di Atom Ginting Munthe, "Terorisme: Gejala Kriminal Media Mutakhir", Jurnal Hukum Pro J usitia, Vol. 25 No. 1 J anuari 2007, hlm. 1-8; Sukawarsini Djelantik, "Terorisme dan Media Massa", Jurnal Hubungan Internasional, PACIS Unpar Bandung, Vol. 1 No. 1.
} 
lihat kegiatan terorisme saat ini, yaitu: pertama, pandangan yang melihat terorisme sebagai kegaiatan yang bersifat politik, baik memilki latar belakang politik, bertujuan politik, maupun kegaiatan yang disponsori oleh kepentingan politik. Pandangan lain, adalah yang melihat kegiatan terorisme sebagai kegiatan kriminal yang merugikan dan membahayakan kehidupan dan perdamaian bangsabangsa $^{25}$. Kedua pandangan yang berbeda secara fundamental tersebut sudah barang tentu, juga membawa pewrbedaan (pandangan) mengenai cara-cara pemberantasannya.

Pandangan yang pertama sering disampaikan dengan justifikasi bahwa untuk mencegah dan memberantas kegiatan terorisme perlu diungkapkan akar dari masalah terorisme. Pandangan kedua, sering disampaikan dengan justifikasi "perlindungan global umat manusia" (global protection for humankind). Kedua, pandangan tersebut akan mempengaruhi pula secara fundamental setiap undang-undang yang kan digunakan guna mencegah dan memberantas tindak pidana terorisme.

Pandangan yang pertama sudah tentu tidak akan setuju dengan undang-undang yang bersifat represif karena masalah ketidak adilan yang merupakan akar masalah terorisme tidak mungkin dapat diselesaikan hanya dengan menangkap, menahan, menuntut, memenjarakan atau mengeksekusi mati pelaknya, melainkan yang harus diutamakan adalah langkah-langkah yang bersifat preventif. Langkah ini antara lain misalnya, mengurangi atau menghilangkan kesenjangan atau ketidak adilann global dalam arti yang seluas-luasnya. Berbeda dengan pandangan pertama, pandangan kedua justru berpendapat bahwa masalah terorisme harus di hadapi dengan pencegahan yang bersifat preemptif dan secara langsung menuntut dan

25 Moch. Faisal Salam, Motivasi Tindakan Terorisme, Mandar Maju, Bandung, 2005, hlm.129. Lihat juga Kent Layne Oots and Thomas C. Wiegele, "Terrorist and Victim: Psychiatric and Physiological Approaches from a Social Science Perspective", Terrorism: An International J ournal, Vol. 8 No. 1, 1985; Political Terrorist: Danger of Diagnosis and an Alternative to the Phychopathology Model", International Journal of Law and Psychiatry, Vol. 8 No. 3, 1986. menghukum para pelakunya setimpal dengan tindak pidana (terorisme) yang dilakukannya.

Mengacu pada deskripsi diatas dapatlah dikatakan bahwa kebijakan internasional dalam penanggulangan dan pemberantasan terorisme saat ini cenderung berorientasi pada pandangan kedua, yakni lebih melihat aksi terorisme sebagai kegiatan kriminal yang harus ditumpas secara represif tanpa memberikan perhatian yang memadai pada upaya mengurangi atau menghilangkan akar masalahnya. Pemilihan terminology "perang" (war on terrorism) oleh AS dan Negara-negara sekutunya sebagai pelopor utama pemberantasan terorisme internasional merupakan salah satu bukti tidak terbantahkan terhadap kecenderungan tersebut. Maksudnya, dalam logika "perang" maka penggunaan semua bentuk kekerasan dan penghancuran (kalau perlu tanpa batas) adalah sesuatu yang lazim dan dibolehkan, sebagaimana perlakuan AS terhadap penghuni penjara Guantanamo (Kuba) dan Abu Ghuraib (Irak).

Jika kita pelajari berbagai konvensi internasional dan resolusi DK serta MU PBB tentang terorisme, maka nampak jelas bahwa kesemua regulasi internasional tentang pemberantasan terorisme saat ini semuanya mengarah pada pandangan yang melihat kegiatan terorisme sebagai kegiatan kriminal (murni) yang harus ditumpas secara represif dan tidak satu pun dari konvensi dan resolusi DK serta MU PBB tersebut yang memberikan penekanan pada perlunya Negara-negara anggota PBB terutama Negara-negara maju untuk bekerjasama mengurangi dan menghilangkan akar dari masalah terorisme, yakni ketidak adilan dan kesenjangan global dalam arti yang seluas-luasnya. Kondisi ini muncul sebenarnya tidak terlalu sulit dipahami, karena sebagaimana diketahui bahwa sebagian besar dari regulasi internasional tersebut lahir atas usul dan tekanan AS sebagai salah salh satu pemilik hak veto di DK PBB, sekaligus sebagai Negara penyumbang terbesar keuangan PBB. Berdasarkan realita ini, maka tidaklah mengherankan jika hampir semua regulasi internasional mengenai penanggulangan terorisme substansinya sangat diwarnai oleh pandangan dan kepentingan (politik, ekonomi 
dan ideologi) AS dalam pemberantasan terrorisme internasional.

Setelah berbagai konvensi dan resolusi DK serta MU PBB mengenai pemberantasan terrorisme lahir, DK PBB sebagai badan eksekutor PBB, kebijakan dan berbagai aksinya juga sangat bias dengan kepentingan AS yang sangat diskriminatif dalam kebijakan polugrinya terutama ketika berhadapan dengan kepentingan Negara sekutu (dekat)nya, yakni Israel. Akibatnya berbagai regulasi dan kebijakan internasional mengenai penanggulangan terosrime, oleh Negara-negara berkembang khususnya Negaranegara Islam dan Negara yang penduduknya mayoritas beragama Islam dirasakan sangat diskriminatif dan tendensius terhadap umat dan dunia Islam.

\section{Implikasi Perkembangan Konstelasi Politik In- ternasional terhadap Politik Hukum Nasional Indonesia dalam pemberantasan Terorisme.}

Pembahasan pada bagian sebelumnya mengenai perkembangan konstelasi politik internasional kontemporer, khususnya paska serangan 11 September 2001 yang telah meluluh lantakkan gedung kebanggaan warga AS, WTC dan sebagian gedung pertahanan AS Pentagon, telah menjelaskan bahwa salah satu cirinya adalah munculnya hegemoni AS yang dalam kebijakan polugrinya telah menjadikan perang melawan terorisme (war on terrorism) sebagai prioritas utama.

Untuk mewujudkan kebijakan polugrinya itu, pemerintah AS menggunakan semua sumber daya yang dimilikinya baik ekonomi, politik dan militer serta mengelompokkan negara lain dalam dua pilihan sulit yakni, bersama AS memerangi terorisme atau jika tidak akan berhadapan dengan AS untuk dihancurkan ("you are against us if you are not with us"). ${ }^{26}$

Lebih dari itu, bahkan beberapa saat paska serangan 11 September 2001, Presiden AS saat itu (George W. Bush) mengeluarkan pernyataan yang sangar provokatif tentang perlu-

26 Lihat Bagas Hapsono, dalam "Catatan Tentang Tulisan Colin L. Powel; "A Strategyof Partnership", Hubungan Internsional: Percikan Pemikiran Diplomat Indonesia, Gramedia Pustka Utama, J akarta, 2004, hlm. 197. nya menyiapkan koalisi internasional guna memerangi terorisme. Dia bahkan menyatakan bahwa perang itu akan menjadi perang salib (grusade) pertama di abad ke $21 .{ }^{27}$

Sekalipun belakangan Bush telah mencabut pernyataannya tersebut dengan mengklaim bahwa hal itu hanya sekedar salah ucap secara tidak sengaja dan yang ia maksudkan sebenarnya adalah memerangi terorisme, setidaknya ucapannya itu mencerminkan sikap Barat (khususnya AS) yang sangat memusuhi Islam.

Bagi Indonesia yang mayoritas penduduknya beragama Islam, dua pernyataan di atas yang menggambarkan kebijakan polugri AS paska serangan 11 September 2001 benar-benar menempatkan pemerintah Indonesia pada posisi sangat sulit.

Sebenarnya, jika sekedar memerangi terorisme, ada atau tidak ada tekanan AS Indonesia tetap akan mendukungnya. Namun permasalahannya muncul ketika Indonesia di hadapkan pada kenyataan bahwa terorisme yang "wajib" diperangi bersama itu adalah terorisme menurut konsep dan terminologi AS, yakni setiap aksi teror yang merugikan kepentingan AS dan negara sekutunya, terutama sekutu dekat AS, Israel.

Bagi masyarakat dan pemimpin negaranegara Barat logikanya sederhana saja, yakni yang mereka vonis pelaku serangan 11 September 2001 adalah Usamah bin Laden dengan Al-Qaedahnya. Usamah bin Laden beragama Islam, karena itu Islam adalah agama teroris.

Tragedi bom Bali 12 Oktober 2002, mengingatkan orang pada kasus peledakan WTC pasa 11 September 2001. Jika kasus WTC menampilkan Al-Qaeda sebagai tertuduh dan membuat AS leluasa memberangus rezim Taliban Afghanistan, diikuti dengan kampanye antiterorisme internasional yang tendensinya mengarah pada pelumpuhan gerakan-gerakan Islam (ideologis) di manca negara, maka kasus bom Bali menampilkan Jama'ah Islamiah sebagai tertuduh dan membuat AS leluasa mene-

27 Lihat, Lathifah Ibrahim Khadhar dalam, "Ketika Barat Menfitnah Islam", Gema Insani Press, Jakarta, 2005, hlm. 128. 
kan Indonesia agar menangkapi atau setidaknya mencurigai kelompok-kelompk Islam yang anti AS dan pro Syari' at Islam serta sesegeranya menyesuaikan regulasi nasionalnya dengan kepentingan AS dalam kampanyenya memerangi terorisme internasional.

Muncul dugaan, bom Bali adalah sebuah rekayasa yang melibatkan kekuatan internasional dalam hal ini AS dengan tujuan mendapatkan pembenaran (justifikasi) aras tuduhan yang sebelumnya sering dilontarkan pihak asing (sekutu AS) bahwa Indonesia adalah sarang teroris. Dugaan itu bukan tanpa alasan. Sampai setahun paska tragedi 11 September 2001, pemerintah Indonesia dinilai tidak pernah memberikan sinyal yang jelas dan tegas terhadap kampanye antiterorisme yang dipelopori AS.

Bahkan Wakil Presiden RI Hamzah Haz saat itu dianggap "pasang badan" dengan terus melakukan "counter opini". Hamzah Haz dalam berbagai kesempatan bahkan menyatakan bahwa di Indonesia tidak ada teroris. Hamzah Haz bahkan kemudian "mengakrabi" tokoh-tokoh Islam yang dicurigai AS sebagai "fundamentalis" seperti Ja'far Umar Thalib (Laskar Jihad), Habib Riziq Shihab (Front Pembela Islam), dan Abubakar Ba'asyir (Majelis Mujahidin Indonesia). Berdasarkan logika ini, maka peledakan bom Bali 12 Oktober 2002 merupakan salah satu upaya AS mementahkan "pembelaan" Hamzah Haz.

Benar atau tidaknya dugaan di atas, agaknya sejarahlah nantinya yang akan menjawab. Tetapi, yang pasti ledakan bom Bali merupakan salah satu pendorong dan alasan utama pemerintah RI mengeluarkan Perppu Antiterorisme yang saat ini telah resmi menjadi Undangundang No. 15 Tahun 2003 tentang Pemberantasan Tindak Pidana Terorisme di Indonesia.

Intervensi dan tekanan AS terhadap kebijakan politik (politik hukum) pemerintah Indonesia dalam pemberantasan terorisme semakin nampak jelas dalam penegakan hukum terhadap (mantan) terpidana kasus terorisme, Abubakar Ba'asyir. Selama proses persidangannya, AS telah melakukan berbagai manufer, antara lain; pertama, mantan Ketua Umum PP Muhammadiyah Prof. Syafii Maarif menulis sendiri kesaksiannya di rubrik Resonansi Harian Umum Republika, ${ }^{28}$ ketika ia diminta langsung oleh Dubes AS di Jakarta Ralph L Boyce agar melobi Ketua MA dan Kapolri supaya Abu bakar Ba'asyir tetap ditahan sebelum pemilu dilangsungkan. Untuk kepentingan itu pihak Dubes menyiapkan semua fasilitas yang dibutuhkan.

Kedua, Fred Burks, mantan penterjemah pertemuan presiden George Bush dan presiden Megawati di Gedung Putih sepekan setelah serangan WTC melansir sendiri kesakisiannya di Washington Post. ${ }^{29}$ Kesaksiannya itu ia ungkapkan kembali ketika ia tampil menjadi saksi ade charge (meringankan) dalam persidangan kasus Abubakar Ba'asyir. Dalam pengakuannya, ia menyebut adanya negosiasi tingkat tinggi, di mana AS meminta Indonesia menyerahkan Abu Bakar Ba'asyir ke tahanan Amerika. ${ }^{30}$ Tetapi Presiden Megawati menolak permintaan tersebut. Fred Burk juga mengungkapkan bahwa tiga pekan sebelum bom Bali, ada pertemuan rahasia di rumah Megawati jalan Teuku Umar yang dihadiri oleh Ralp L Boyce, dubes AS untuk Indonesia, Karen Brooks (Direktur Asia National Security Council), seorang perempuan agen $\mathrm{ClA}$ yang diperkenalkan sebagai asisten khusus Bush, dan Burks sendiri. Dalam pertemuan itu si agen CIA berkata bahwa pemerintah AS minta agar Abubakar Ba'asyir di-render (diserahkan secara rahasia) kepada AS karea terkait dengan jaringan Al-Qaeda.

Megawati menolak, dengan alasan kalau dia menyerahkan Abubakar Ba' asyir ke Amerika akan timbul instabilitas politik dan agama yang tidak akan sanggup ia tanggung. Namun si agen $\mathrm{CIA}$ itu justru mengancam: “jika Ba'asyir tidak diserahkan ke Amerika sebelum Konferensi APEC (enam minggu setelah pertemuan itu) maka "situasi akan semakin sulit". Pertemuan pun bubar, tapi tiga pekan kemudian bom Bali pun meledak.

Ketiga, Pemerintah AS pernah mengutus Menteri Keamanan Dalam Negeri AS Tom Ridge pada 10 Maret 2004 untuk menekan Presiden

28 Republika, edisi 13 April 2004.

29 Washington Post, edisi 9 Desember 2004.

30 Lihat, Fred Burk, "Saya tak Takut diburu Pemerintah Amerika", harian Padang Ekspres, edisi Sabtu, 15 J anuari 2005. 
Megawati, Menko Polkam SBY, dan Kapolri Jenderal Da'i Bakhtiar agar tetap menahan Ba'asyir setelah bebas dari Rutan Salemba. Hasilnya ribuan polisi $\mathrm{HPH}$ mengambil paksa Ba'asyir pada hari J um' at 30 April 2004 pukul 06.55 setelah sebelumnya sempat bentrok dengan para aktifis MMI dan beberapa Ormas Islam lain sejak pukul 05.00 bakda sholat Subuh. Keempat, sehari setelah keluarnya keputusan MA yang membebaskan Ba'asyir dari tuduhan teroris, pemerintah AS dan Australia langsung bereaksi keras atas putusan MA tersebut.

Berdasarkan fakta sebagaimana terungkap di atas, jelaslah bahwa politik hukum nasional Indonesia dalam pemberantasan terorisme sulit dilepaskan dari bayang-bayang perkembangan konstelasi politik internasional, terutama perkembangan konstelasi politik internasional paska serangan 11 September 2001 terhadap WTC yang ditandai dengan dijadikannya peraang terhadap terorisme sebagai prioritas utama kebijakan polugri AS sampai saat ini.

Berdasarkan fakta yang ada paling tidak kita juga bisa melihat bahwa secara politis, penangkapan dan penahanan Ba'asyir dengan tuduhan teroris memiliki tujuan ganda. Pertama, menunjukkan kepada AS bahwa pemerintah RI serius memerangi terorisme, sekaligus untuk menunjukkan "kepatuhan" Indonesia atas "order"nya.

Kedua, menjustifikasi diberlakukannya Perppu No. 1 Tahun 2002 tentang Tindak Pidana Terorisme dan Perppu No. 2 Tahun 2002 tentang Pemberlakuan Perppu No. 1 Tahun 2002 pada peledakan bom Bali 12 Oktober 2002, yang sekaligus bisa digunakan untuk membidik kalangan aktifis Islam yang selama ini didefinisikan sebagai tokoh radikal dan anarkis. Kalangan yang dituding "radikal" tersebut tidak lain adalah orang-orang seperti Abubakar Ba' asyir yang (memang) anti AS dan pro syari'at Islam serta mereka yang didefinisikan agenagen AS dan PBB sebagai "anggota jaringan teroris" J ama' ah Islamiyah atau Al-Qaidah.

Konstelasi politik Indonesia yang diwarnai dinamika benturan kepentingan antara kelompok nasionalis-sekuler dan nasionalis-religius (kelompok Islam) turut terkena dampak isu terorisme. Bahkan, kampanye perburuan terhadap terorisme yang sebenarnya merupakan agenda politk AS, dijadikan pula agenda politik. pemerintah Megawati yang nota bene dari kelompok nasionalis-sekuler.

Berdasarkan logika ini, maka tidak ayal kalau ada komentar kritis yang mengatakan bahwa jelas sekali terdapat pertemuan kepentingan antara kekuatan politik domestik Indonesia (nasionalis-sekuler) dengan AS untuk menyudutkan kelompok Islam. Karena itu, agenda terorisme AS dijalankan pula oleh pemerintahan Megawati, nyaris tanpa reserve. Sasarannya sama, melemahkan kekuatan (politik) kelompok Islam Indonesia. ${ }^{31}$

Untuk lebih jelasnya mengenai pertarungan kepentingan elit politik domestik antara fraksi nasionalis-sekuler dengan fraksi nasionalis-religius tersebut, Kontras ${ }^{32}$ menggambarkannya melalui skema sebagai berikut :

\section{Skema}

Peta Aktual Pertarungan Elit Politik Fraksi Nasional

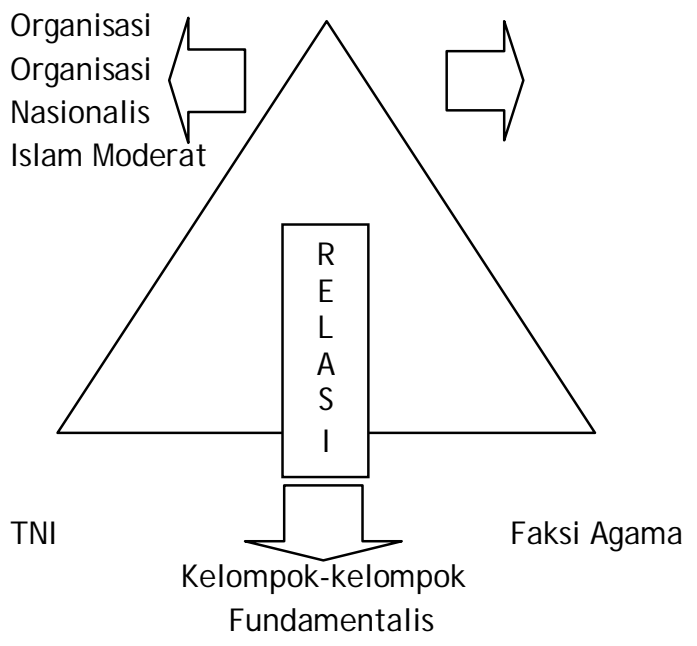

Berdasarkan skema di atas, tergambar bahwa masing-masing faksi membangun aliansi dengan berbagai kelompok dan pada tingkatan

31 Komentar kritis mengenai hal ini pernah dikemukakan oleh cendekiawan Muslim, Alm. Nurcholis Madjid, yang melontarkan teori kemungkinan adanya "konspirasi asing dan domestik" yang sama-sama membidik kelompok Islam.

32 Lihat, Kontras, dalam "Analisis Kasus Peledakan Bom Bali: Mengapa "teror" Terjadi?", Imparsial, Jakarta, 2005, hlm. 40. 
tertentu terdapat kelompok yang sama yang menjadi target aliansi. Kelompok nasionalissekuler dalam praktek pada umumnya sangat pragmatis dalam membangun aliansi dengan fraksi manapun asal tujuan (politik) mereka tercapai, termasuk membangun aliansi dengan kekuatan asing yang kebetulan sama-sama memiliki agenda politik yang sama dengan mereka.

Sebaliknya kelompok nasionalis-religius memiliki kecenderungan melakukan aliansi dengan semua kelompok agama, termasuk dengan kelompok fundamentalis sekalipun dan kondisi inilah yang sering dijadikan "sasaran tembak" oleh kelompok nasionalis-sekuler untuk dijadikan isu politik dalam menggaet kekuatan asing (Barat) untuk melakukan aliansi buat memenangkan pertarungan dengan melemahkan kekuatan kelompok Islam.

Kesan kuat bahwa politik hukum nasional Indonesia dalam pemberantasan terorisme terimplikasi oleh perkembangan konstelasi politik internasional kontemporer juga diamini oleh Daniel S. Lev, seorang warga AS pengamat senior dari Washington University yang juga pemerhati hukum dan politik Indonesia yang menyatakan bahwa:

"Gerakan anti terorisme di Indonesia merupakan desakan Negara-negara Barat termasuk AS dan Australia. Namun, pemerintah Indonesia hendaknya tidak begitu saja menuruti desakan itu. Pemerintah Indonesia jangan mengorbankan kepentingan nasional jangka panjang dalam berbagai program pembangunannya demi kepentingan jangka pendek AS". ${ }^{33}$

Pendapat yang kurang lebih juga senada dengan pandangan Daniel S. Lev di atas dikemukakan oleh Munawarman, mantan direktur LBH J akarta, yang menyatakan:

"Perlu pula kami sampaikan dalam kesempatan ini, bahwa apa yang ada dibalik "perang terhadap terorisme" (war on terrorism) ini sesungguhnya adalah perang terhadap keyakinan dan paham politik yang bertentangan dengan

\footnotetext{
33 Harian Republika, edisi 11 Nopember 2002.
}

keyakinan dan paham politik yang dianut oleh Amerika Serikat dan sekutunya". ${ }^{34}$

Berdasarkan uraian dan pandangan-pandangan di atas dapat dikatakan bahwa politik hukum pemerintah Indonesia dalam pemberantasan terorisme sulit dilepaskan dari pengaruh tekanan negara-negara asing, terutama pengaruh tekanan pemerintah AS dan sekutunya. Bahkan, peledakan bom Bali, 12 Nopember 2002 yang menyebabkan kurang lebih 190 orang korban tewas tanpa ada seorangpun warga AS yang jadi korban, dan telah dijadikan sebagai alasan utama pemerintah RI mengeluarkan Perppu Antiterorisme, juga sulit dilepaskan dari bau konspirasi AS untuk menampilkan bukti adanya jaringan teroris internasional di Indonesia.

\section{Penutup \\ Simpulan}

Sebagai bagian akhir dari tulisan ini, penulis ingin mengemukakan beberapa simpulan. Pertama, politik hukum nasional Indonesia dalam pemberantasan terorisme belum sesuai dengan prinsip-prinsip negara hukum yang berdasarkan Pancasila dan UUD-1945, karena kurang menghormati nilai-nilai dan lembagalembaga agama, kurang menghormati dan melindungi hak-hak asasi manusia, berpotensi mengancam integrasi bangsa, kurang menghormati nilai-nilai demokrasi dan kurang memenuhi rasa keadilan rakyat dan bangsa Indoenesia.

Kedua, perkembangan konstelasi politik internasional dalam kaitannya dengan pemberantasan terorisme dewasa ini sangat di dominasi oleh kepentringan politik, ekonomi dan ideologi AS, baik dalam regulasinya dalam berbagai konvensi internasional, resolusi DK dan MU PBB, begitu juga dalam penerapan dan penegakan hukumnya. Kondisi ini dirasakan tidak sesuai dengan prinsip-prinsip negara hukum yang demokratis, karena sering menggunakan standar ganda, tidak menghormati hak-hak asasi terdakwa serta tidak menghormati asas pra-

34 Terpetik dalam "Pengadilan Rekayasa Ustad Abubakar Ba'asyir", op. cit, hlm. Xl. 
duga tidak bersalah dan asas persamaan di depan hukum.

Ketiga, perkembangan konstelasi politik internasional berimplikasi cukup signifikan terhadap politik hukum nasional Indonesia dalam pemberantasan terorisme, baik dalam proses pembentukannya begitu juga dalam proses penerapan dan penegakan hukumnya. Kelahiran UU Nomor 15 Tahun 2003 tentang Pemberantasan Tindak Pidana Terorisme, selain kurang memiliki landasan filosofis dan yuridis yang kuat, penerapannya juga cenderung sangat diskriminatif dan tendensius terhadap umat Islam.

\section{Saran}

Beberapa saran yang dapat diberikan berdasar pada permasalahan yang diajukan antara lain. Pertama, agar politik hukum internasional dalam pemberantasan terorisme lebih sesuai dan sejalan dengan asas-asas negara hukum yang demokratis, maka disarankan agar pemerintah Indonesia mendesak lembaga-lembaga internasional yang berkompeten untuk sesegeranya menetapkan rumusan terorisme secara jelas dan seobjektif mungkin, serta mendesak lembaga internasional agar menekan pemerintah AS untuk meninggalkan kebijakan polugri standar ganda (double standard) terutama di Timur Tengah yang diyakini banyak kalangan merupakan akar dari berbagai aksi terorisme internasional.

Pemerintah Indonesia juga disarankan agar menggunakan semua sumber daya yang dimilikinya untuk memperjuangkan duduknya salah satu negara Islam atau negara berpenduduk mayoritas Muslim sebagai anggota tetap DK-PBB mewakili dunia Islam, sehingga struktur komposisi anggota tetap DK-PBB pemilik hak veto di lembaga eksekutor PBB tersebut dapat menampakkan wajah yang lebih representaif dan demokratis.

Kedua, perlu segera dilakukan amandemen terhadap beberapa pasal dalam UU No. 15 Tahun 2003 tentang Pemberantasan Tindak Pidana Terorisme, terutama berkaitan dengan pemberian kewenangan sangat luas kepada lembaga-lembaga non-judisial untuk ikut serta dalam proses penyidikan dan penyelidikan ka- sus-kasus terorisme sebagaimana dulu pernah dijanjikan oleh pemerintah sewaktu UU Terorisme masih dalam bentuk Perppu, sehingga politik hukum nasional Indonesia dalam pemberantasan terorisme lebih memenuhi rasa keadilan sosial.

Ketiga, agar politik hukum nasional Indonesia dalam pemberantasan terorisme ke depan dapat lebih memenuhi prinsip-prisip negara hukum berdasarkan Pancasila dan UUD-1945, maka perlu upaya lebih serius dalam peningkatan profesionalisme dan integritas baik aparat pembentuk hukum (DPR-RI), begitu juga aparat penegak hukum (kepolisian, aparat kejaksaan dan pengadilan). Khusus berkaitan dengan lembaga Densus 88 Antiteror, perlu dilakukan pembenahan organisasi terutama pada aspek ideologi komandan dan petugas lapangan, bahwa terorisme tidak ada kaitannya dengan ajaran agama manapun.

Keempat, disarankan kepada peneliti lain agar melakukan kajian mengenai relasi dan implikasi perkembangan konstelasi politik internasional terhadap produk-produk hukum nasional Indonesia lainnya, terutama produk hukum nasional yang memiliki muatan ideologi dan aspek internasional yang kuat, seperti UU PMA, UU BUMN, UU Migas, UU Pornografi serta UU Mineral dan Batubara (UU Minerba)

\section{Daftar Pustaka}

Alesina, Ozler dan Swagel. "Political Instability and Economic Growth" J ournal of Economic Growth, Vol. 1, 1996;

Djelantik, Sukawarsini. "Terorisme dan Keamanan Nasional". Jurnal IImu Hubungan Internasional, Vol. 1 No. 1 Centre for International Studies. Bandung: Unpar;

------. "Terorisme dan Media Massa". Jurnal Hubungan Internasional, Vol. 1 No. 1. Bandung: PACIS Unpar;

Fell, Mike. "Is Human Security Our Main Concern in the $21^{\text {st }}$ ". J Journal of Security Sector Management, Vol. 4 No. 3, September 2006;

Hapsono, Bagas. 2004. "Catatan Tentang Tulisan Colin L. Powel; "A Strategyof Partnership", Hubungan Internsional: Percik- 
an Pemikiran Diplomat Indonesia. Jakarta: Gramedia Pustaka Utama;

Hapsoro, Bagas. 2004. Hubungan Internasional: Percikan Pemikiran Diplomat Indonesia J akarta: Deparlu Rl;

Holsty, K.J . 1987. Politik Internasional (Kerangka Analisa). J akarta: Pedoman IImu J aya;

Husaini, Adrian. Liberalisasi Islam di Indonesia. Makalah disampaikan dalam forum kerjasama Pondok Pesantren Indonesia (BKSPPI). Bogor, 2 April 2006;

2005. Wajah Peradaban Barat: Dari Hegemoni Kristen ke Dominasi Sekular-Liberal. J akarta: GIP;

Interim Report. Revitalisasi Proses Pembuatan Kebijak-an Luar Negeri Indonesia Menghadapi Perkembangan Internal dan Eksternal. Laporan Penelitian, Deparlu RI, 2002;

J ones, Sidney. "Sayap Garis Keras itu Bernama Thoifah Muqatilah". Majalah Tempo Eisi 17-23 Oktober 2005;

Khadhar, Lathifah Ibrahim. 2005. Ketika Barat Menfitnah Islam. Jakarta: Gema Insani Press;

Kontras. 2005. "Analisis Kasus Peledakan Bom Bali: Mengapa "teror" Terjadi?". Jakarta: Imparsial;

Lim, Merlina. "Islamic Radicalism and AntiAmericanism in Indonesia, The Role of the Internet". Policy Study, No. 18, 2005;

Mesqueta, Ethan Bueno de. "The Quality of Terror". American Journal of Political Science 2005;
Munthe, Atom Ginting. "Postur "Rasionalis" dalam Politik Luar Negeri Indonesia Pasca Suharto". J urnal Hukum Pro J usitia, Vol. 24 No. 3 J uli 2006;

Munthe, Atom Ginting. "Terorisme: Gejala Kriminal Media Mutakhir". J urnal Hukum Pro J usitia, Vol. 25 No. 1 J anuari 2007;

Oots, Kent Layne and Thomas C. Wiegele. "Political Terrorist: Danger of Diagnosis and an Alternative to the Phycho-pathology Model". International J ournal of Law and Psychiatry, Vol. 8 No. 3, 1986;

Oots, Kent Layne and Thomas C. Wiegele. "Terrorist and Victim: Psychiatric and Physicological Approaches from a Social Science Perspective". Terrorism: An International J ournal, Vol. 8 No. 1, 1985;

Pekuali, Umbu Lily. "Memposisikan Hukum sebagai Penyeimbang Kepentingan Masyarakat". J urnal Pro Justitia, Vol. 26 No. 4 Oktober 2008. FH Unpar Bandung;

Perwita, Anak Agung Banyu. "Penegakan HAM dan Politik Luar Negeri Indonesia". J urnal Hukum Pro Jusitita, Vol. 24 No. 2 April 2006;

Salam, Moch. Faisal. 2005. Motivasi Tindakan Terorisme, Bandung: Mandar Maju;

Syihab, Al-Habib Muhammad Rizieq bin Husein. "Sumpah Usamah". Majalah Islam Sabili, No. 12 Tahun X, 2 J anuari 2003/29 Syawal 1423;

Wadj di, Farid. 2003. Kebencian Barat Terhadap Gerakan Islam Idiologis. Jakarta: Wahyu Press. 